University of Nebraska - Lincoln

DigitalCommons@University of Nebraska - Lincoln

USDA National Wildlife Research Center - Staff Publications
U.S. Department of Agriculture: Animal and Plant Health Inspection Service

April 2003

\title{
AGE-SPECIFIC REPRODUCTION BY FEMALE LAUGHING GULLS (LARUS ATRICILLA)
}

Richard A. Dolbeer

U.S. Department of Agriculture, Wildlife Services, National Wildlife Research Center

Glen E. Bernhardt

U.S. Department of Agriculture, Wildlife Services, National Wildlife Research Center

Follow this and additional works at: https://digitalcommons.unl.edu/icwdm_usdanwrc

Part of the Environmental Sciences Commons

Dolbeer, Richard A. and Bernhardt, Glen E., "AGE-SPECIFIC REPRODUCTION BY FEMALE LAUGHING GULLS (LARUS ATRICILLA)" (2003). USDA National Wildlife Research Center - Staff Publications. 139. https://digitalcommons.unl.edu/icwdm_usdanwrc/139

This Article is brought to you for free and open access by the U.S. Department of Agriculture: Animal and Plant Health Inspection Service at DigitalCommons@University of Nebraska - Lincoln. It has been accepted for inclusion in USDA National Wildlife Research Center - Staff Publications by an authorized administrator of DigitalCommons@University of Nebraska - Lincoln. 


\title{
AGE-SPECIFIC REPRODUCTION BY FEMALE LAUGHING GULLS (LARUS ATRICILLA)
}

\author{
Richard A. Dolbeer ${ }^{1}$ AND GLEN E. BernhardT \\ U.S. Department of Agriculture, Wildlife Services, National Wildlife Research Center, \\ 6100 Columbus Avenue, Sandusky, Ohio 44870, USA
}

\begin{abstract}
The age at which female gulls first reproduce is poorly documented. We examined plumage and reproductive organs of Laughing Gulls (Larus atricilla) collected from May-August 2000-2001 at John F. Kennedy International Airport, New York, to determine age-specific reproductive effort. Each gull was classified as one year old (hatched in previous year), two years old, or $\geq 3$ years old on the basis of color patterns of the hood and tail feathers and fifth primary flight feather. For females, each ovary was examined to determine if postovulatory follicles were present. In 2000 and 2001, the first gulls with postovulatory follicles were recorded on 15 and 18 May, respectively. Overall, 54\% of the 211 two-year-old female Laughing Gulls collected during June-August showed evidence of egg laying compared to $88 \%$ of the 320 gulls $\geq 3$ years old. None of the 50 one-year-old females examined showed evidence of egg laying. Although a lower proportion of two-year-old females laid eggs compared to older gulls, we found no difference $(P \geq 0.06)$ in mean number of postovulatory follicles or in frequency distribution of numbers of postovulatory follicles for the two age classes for those birds that did lay eggs. Within each sex, mean body mass increased $(P<0.05)$ with age. Mean left testis length of males increased $(P<0.05)$ with age. Our findings clearly established that two-year-old female Laughing Gulls can contribute significantly to the annual reproductive effort and that some adult ( $\geq 3$ years old) females did not lay eggs. Received 30 June 2002, accepted 14 December 2002.
\end{abstract}

RESUMEN.—La edad a la que las gaviotas hembras se reproducen por primera vez está pobremente documentada. Para determinar el esfuerzo reproductivo de aves de diferentes edades, estudiamos el plumaje y los órganos reproductivos de gaviotas Larus atricilla colectadas entre mayo y agosto de 2000 y 2001 en el Aeropuerto Internacional John F. Kennedy de Nueva York. Con base en los patrones de coloración de la capucha, las plumas de la cola y la quinta pluma primaria de vuelo, cada gaviota fue clasificada como de un año (nacida el año anterior), de dos años, o de 3 o más años de edad. En las hembras, cada ovario fue examinado para determinar la presencia de folículos post-ovulatorios. Las primeras gaviotas con folículos post-ovulatorios fueron registradas el 15 y 18 de mayo en 2000 y 2001, respectivamente. El 54\% de las 211 gaviotas hembras de dos años de edad colectadas entre junio y agosto mostraron evidencia de haber puesto huevos, en comparación con el $88 \%$ de las 320 gaviotas de 3 años o más. Ninguna de las 50 hembras añales examinadas mostró evidencia de haber puesto huevos. Aunque una menor proporción de las gaviotas de 2 años pusieron huevos en comparación con las de mayor edad, no encontramos diferencias $(P \geq 0.06)$ en el número promedio de folículos post-ovulatorios ni en la distribución de frecuencias del número de folículos post-ovulatorios para las dos clases de edad en aquellas aves que pusieron huevos. En cada sexo, el peso corporal promedio aumentó con la edad $(P<0.05)$, al igual que la longitud promedio del testículo izquierdo de los machos $(P<0.05)$. Nuestros hallazgos establecen claramente que las gaviotas L. atricilla hembras de dos años de edad pueden contribuir significativamente al esfuerzo reproductivo anual, y que algunos individuos adultos (de tres o más años) no pusieron huevos.

THE AgE AT Which gulls (Larus spp.) initially reproduce is assumed to correlate with the age adult plumage is achieved, ranging from two years (when year $0=$ year in which gull hatched) in small species such as Bonaparte's Gulls (L. philadelphia) to four years in large

${ }^{1}$ E-mail: richard.a.dolbeer@usda.gov species such as Great Black-backed Gulls (L. marinus; Grant 1986). However, for most species, objective data are lacking to document the age when reproduction first occurs and the proportion of birds breeding in each age class (e.g. Good 1998, Pierotti and Good 1994, Ryder 1993). For Laughing Gulls (L. atricilla), Burger (1996) noted that based on banding data, the youngest breeders were three years old, but 
there was "no definite information" regarding age of first breeding.

We had an opportunity to obtain data on age-specific reproduction for female Laughing Gulls at John F. Kennedy International Airport (JFKIA) in New York City. Since 1991, biologists at JFKIA have used shotguns to shoot gulls attempting to fly over the airport from a nearby $(<1 \mathrm{~km})$ nesting colony in marshes in Jamaica Bay during May to early August (Dolbeer et al. 1993, Dolbeer 1999). During 2000-2001, we examined plumage and reproductive organs of Laughing Gulls that were shot to determine age-specific reproductive effort. Our primary objective was to determine if Laughing Gulls flying over the airport were nonbreeding birds or birds that nested in the nearby colony (the next nearest colony was $100 \mathrm{~km}$ south in New Jersey; Belant and Dolbeer 1993). A secondary objective was to determine proportion of female gulls in each age class that produced eggs and mean clutch size for those birds laying eggs. In addition, we determined mean testis length for males and mean oviduct diameter for females by age class.

\section{Methods}

Gulls were collected by biologists using 12-gauge shotguns on 50 days from 11 May to 8 August 2000 and 42 days from 16 May to 7 August 2001. Two to five shooters were stationed on JFKIA property along the $5-\mathrm{km}$ southern boundary with Jamaica Bay where gulls often crossed the airport (Dolbeer et al. 1993). Shooting typically was conducted from $0430-1100$ hours EST.

Shot Laughing Gulls were labeled, bagged, and frozen before shipment to Sandusky, Ohio for autopsy. After thawing and before necropsy, each gull was weighed to the nearest gram. Each gull then was classified as 1 year old (hatched in previous year), 2 years old, or $\geq 3$ years old based on color patterns of the hood and tail feathers and fifth primary flight feather. In a previous study, Belant and Dolbeer (1996) used those criteria to correctly age $98 \%$ of 244 known-aged (i.e. banded as nestlings) Laughing Gulls. Sex was determined by necropsy and visual examination of reproductive organs. Maximum diameter of the oviduct (females) and the length of the left testis (males) were measured to the nearest millimeter. Each ovary was further examined under $10 \times$ magnification to determine if postovulatory follicles were present, indicative of egg laying in the current reproductive season (Pearson and Rohwer 1998). The oviduct, which was smooth and straight in gulls with no postovulatory follicles and striated and convoluted in gulls with postovulatory follicles, also was used to confirm egglaying status.

Proportion of females with postovulatory follicles and distribution of number of postovulatory follicles per ovary were compared between age classes by chi-square tests (STATISTIX 2000). One-way ANOVA was used to compare means among age classes for body mass, testis length, and oviduct width; individual means were compared a posteriori by the least significant difference method (Steel and Torrie 1980, STATISTIX 2000).

\section{RESUlts}

In $2000-2001,41 \%$ of the 302 2-year-old female Laughing Gulls collected during from May through August showed evidence of egg laying, which was a lower proportion $(P<0.01$, Table 1$)$ compared to $79 \%$ of the 386 gulls $\geq 3$ years old. None of the 50 one-year-old females examined showed evidence of laying eggs. In 2000 and 2001, the first gulls with postovulatory follicles were recorded on 15 and 18 May, respectively. If we exclude data from May, to eliminate those gulls that would have nested but were collected before they initiated egg laying at the start of nesting season, $54 \%$ of the autopsied female Laughing Gulls 2 years old showed evidence of egg laying in contrast to $88 \%$ of $\geq 3$ year old females $(P<0.01$, Table 1$)$.

Although a lower proportion of two-year-old females laid eggs compared to older gulls, we found no difference in mean number of eggs laid (based on number of postovulatory follicles counted) or in frequency distribution of numbers of postovulatory follicles for the two age classes for those birds that did lay eggs (Table 2). Modal number of postovulatory follicles recorded was 3. Six $(4.8 \%)$ of the 2-year-old females had five or more postovulatory follicles compared to 18 $(6.3 \%)$ of the females $\geq 3$ years old.

Mean length of left testis was different $(P<0.05)$ for 1,2 , and $\geq 3$-year-old males and showed the same pattern of decline for the three age classes from May through August (Fig. 1). Likewise, the mean maximum diameter of the oviduct differed $(P<0.05)$ among the three age classes and declined from May to early June through August (Fig. 1).

Mean body mass for males was $12 \%$ greater $(P<0.01)$ than for females (Table 3$)$. Within each sex, mean body mass increased $(P<0.05)$ with age. For females and males, mean body mass of 2 and $\geq 3$-year-old gulls were $4-5 \%$ and $6-7 \%$ 
TABLE 1. Percent of Laughing Gulls that laid eggs in 2000-2001 in a sample of 740 females (324 in 2000; 416 in 2001) collected at John F. Kennedy International Airport, May-August, based on examination of reproductive tracts.

\begin{tabular}{|c|c|c|c|c|c|c|}
\hline \multirow[b]{3}{*}{ Dates collected } & \multicolumn{6}{|c|}{ Number examined $(n)$ and percent laying eggsa by age class } \\
\hline & \multicolumn{2}{|c|}{ One-year-old } & \multicolumn{2}{|c|}{ Two-years old } & \multicolumn{2}{|c|}{$\geq 3$ years old } \\
\hline & $n$ & $\%$ laying & $n$ & $\%$ laying & $n$ & $\%$ laying \\
\hline 11-31 May b & 9 & 0 & 91 & 12 & 66 & 35 \\
\hline 1-30 June & 32 & 0 & 125 & 43 & 141 & 84 \\
\hline 1-31 July & 4 & 0 & 57 & 74 & 140 & 91 \\
\hline 1-8 August & 5 & 0 & 29 & 59 & 39 & 92 \\
\hline June-August onlyc & 41 & 0 & 211 & 54 & 320 & 88 \\
\hline May-August ${ }^{c}$ & 50 & 0 & 302 & 41 & 386 & 79 \\
\hline \multicolumn{7}{|c|}{$\begin{array}{l}\text { a One or more postovulatory follicles were found in ovary, and oviduct showed striations and convolutions indicating egg laying. } \\
\text { Fifty-two gulls shot from } 3 \text { July to } 8 \text { August were classified as laying eggs even though the precise number of postovulatory follicles } \\
\text { was difficult to count because of advanced absorption. In those gulls, postovulatory follicles were visible, and the oviducts still showed } \\
\text { clear striations and convolutions. } \\
\text { ' In } 2000 \text { and } 2001 \text {, the first gulls with postovulatory follicles were recorded on } 15 \text { and } 18 \mathrm{May} \text {, respectively. } \\
\text { c Proportion of } 2 \text { - and } \geq 3 \text {-year-old females with postovulatory follicles is different }\left(\chi^{2}=104.0, \mathrm{df}=1, P<0.01 \text { for May-August; } \chi^{2}=\right. \\
78.1, \mathrm{df}=1, P<0.01 \text { for June-August). }\end{array}$} \\
\hline
\end{tabular}

greater, respectively, than the mean mass of one-year-old birds.

\section{DisCUSSION}

The age at which Laughing Gulls first breed was previously unknown (Burger 1996). Our findings clearly established that two-year-old females can contribute significantly to the annual reproductive effort. About $54 \%$ of two-year-old female Laughing Gulls collected in June-August had laid eggs. Although a lower percentage of 2-year-old females than $\geq 3$-year-old females laid eggs, mean clutch size was similar for the two age groups for those females laying eggs. We also determined that not all females $\geq 3$ years old reproduced annually; $12 \%$ of those older birds collected in June-August showed no evidence of laying eggs. Laughing Gulls have a maximum age of $>13$ years (Dolbeer and Belant 1994).

In 2000 and 2001, the first gulls with postovulatory follicles were recorded on 15 and 18 May, respectively. Those dates are consistent with previous findings that nest building and egg laying for Laughing Gulls in the mid-Atlantic region typically occur during the last half of May (Buckley and Gurien 1986, Burger 1996).

Mean left testis length was $\sim 30 \%$ less for 2year-old males compared to $\geq 3$-year-old males during May when most copulations would presumably occur (Burger 1996). That disparity in size suggests that two-year-old males contribute less to the reproductive effort than do older males.

We caution that the large percentage of twoyear-old females laying eggs in 2000 and 2001

TABLE 2. Distribution of number of postovulatory follicles (POF) for 2 and $\geq 3$-year-old female Laughing Gulls collected at John F. Kennedy International Airport, May-August, 2000-2001. This sample excludes gulls having no postovulatory follicles when collection was made, or where follicles were present but exact number was difficult to ascertain because of absorption (see Table 1).

\begin{tabular}{|c|c|c|c|c|c|c|}
\hline \multirow{2}{*}{$\begin{array}{c}\text { Age } \\
\text { (years) }\end{array}$} & \multirow[b]{2}{*}{$n$} & \multicolumn{4}{|c|}{ Number (\%) of gullsa } & \multirow{2}{*}{$\begin{array}{c}\text { Mean (SD) number } \\
\text { of POF c }\end{array}$} \\
\hline & & $1 \mathrm{POF}$ & 2 POF & 3 POF & $\geq 4 \mathrm{POF}^{\mathrm{b}}$ & \\
\hline 2 & 124 & $14(11)$ & $13(11)$ & $89(72)$ & $8(6)$ & $2.83(0.97)$ \\
\hline$\geq 3$ & 288 & $16(6)$ & $25(9)$ & $224(78)$ & $23(8)$ & $3.03(1.06)$ \\
\hline Total & 412 & $30(7)$ & $38(9)$ & $313(76)$ & $31(8)$ & $3.00(1.03)$ \\
\hline
\end{tabular}

a Proportion of gulls with 1, 2, 3, and $\geq 4$ POFs did not differ between 2-year-old and $\geq 3$ year-old gulls $\left(\chi^{2}=4.9, \mathrm{df}=3, P=0.17\right)$.

b Six 2-year-old gulls had $\geq 5$ POFs; $18 \geq 3$-year-old gulls had $\geq 5$ POFs, including 1 gull with 8 POFs and 2 gulls with 9 POFs.

c Mean number of POFs did not differ between 2-year-old and $\geq 3$-year-old gulls $(F=3.46, \mathrm{df}=1$ and $410, P=0.06$ ). 

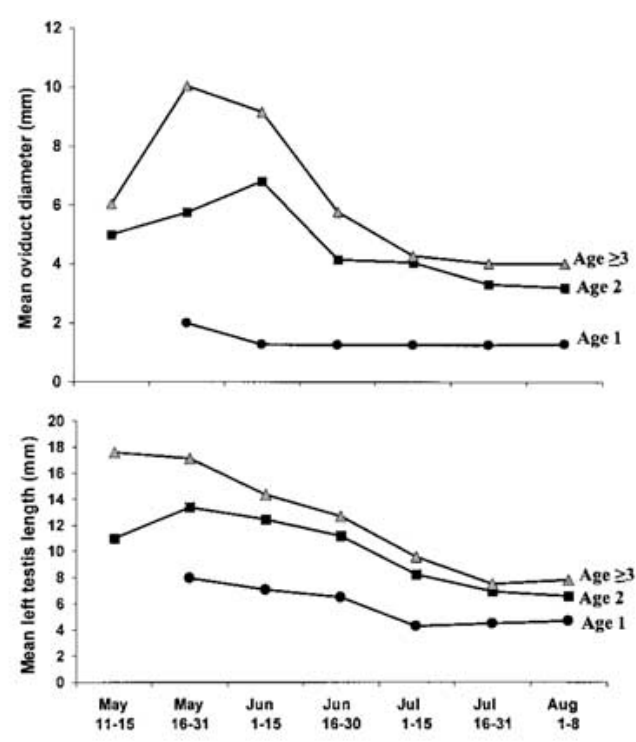

FIG. 1. Mean length of left testis and mean maximum width of oviduct for male and female Laughing Gulls 1,2 , and $\geq 3$ years old, John F. Kennedy International Airport, 11 May to 8 August 2000-2001. Mean testis length differed $(F=99.9, \mathrm{df}=2$ and 1,075, $P<0.01)$ among the three age classes and all three means differed $(P<0.05)$. Mean oviduct diameter also differed $(F=32.9, \mathrm{df}=2$ and $738, P<0.01)$ among the three age classes and all three means differed $(P<0.05)$.

may not be typical for Laughing Gull colonies that, unlike the Jamaica Bay colony, are unexploited. The Laughing Gull nesting colony in Jamaica Bay adjacent to JFKIA has been present since 1979 . The colony contained an estimated 2,720 nests in 2000 and 4,310 nests in 2001 (Dolbeer et al. 1997, 2002). The closest Laughing Gull colony was in New Jersey, $106 \mathrm{~km}$ from JFKIA (Belant and Dolbeer 1993). Biologists at JFKIA shot 3,606 and 3,194 Laughing Gulls flying across the airport during 2000 and 2001, respectively (Dolbeer et al. 2002). That removal may have presented opportunities for two-yearold females to nest that would not have been available in an unexploited population.

We also documented that a small percentage of 2 and $\geq 3$ year old females renested within a reproductive season. The modal clutch size for Laughing Gulls is 3 eggs with a range of 2-4 (Burger 1996). If we assume that gulls with five or more postovulatory follicles renested (i.e. produced another clutch of eggs presumably after a failed nesting attempt), then $5-6 \%$ of the birds we examined laid more than one clutch. Three gulls had eight or nine postovulatory follicles, indicating two renesting attempts by those birds.

We also documented that both male and females Laughing Gulls had mean gains in body mass of about $4-5 \%$ from 1 year old to 2 years old and $2-3 \%$ from 2 years old to $\geq 3$ years old. Schreiber and Schreiber (1979) previously documented that for both male and female Laughing Gulls in Florida, adult ( $\geq 2$ years old) birds had greater body masses than birds $<1$ year old. We are unaware of studies that have documented increased body mass over three age classes in gulls.

\section{ACKNOWLEDGMENTS}

We thank T. L. Boscoe, L. C. Francoeur, A. J. Graser, S. Nowak, and R. Junge of the Port Authority of New York and New Jersey for their support and S. C. Barras, L. K. Brohl, R. B. Chipman, J. T. Gansowski, A. L. Gosser, K. Maderas, and K. J. Preusser of the U.S. Department of Agriculture for field and laboratory assistance. Birds were collected under federal U.S. Fish and Wildlife permits (Depredation) MB816581-0 and MB816581-1 issued by the U.S. Fish and Wildlife Service and New York State Fish and Wildlife License

TABLE 3. Mean body mass (grams) by sex and age class for Laughing Gulls collected at John F. Kennedy International Airport, May-August, 2000-2001.

\begin{tabular}{|c|c|c|c|c|c|c|}
\hline \multirow{2}{*}{$\begin{array}{c}\text { Age } \\
\text { (years) }\end{array}$} & \multicolumn{3}{|c|}{ Males } & \multicolumn{3}{|c|}{ Females } \\
\hline & $n$ & Mean ${ }^{a}$ & SD & $n$ & Mean ${ }^{\mathrm{b}}$ & SD \\
\hline 1 & 94 & $320 \mathrm{~A}$ & 29 & 50 & $290 \mathrm{~A}$ & 29 \\
\hline 2 & 437 & 335B & 31 & 309 & 301B & 27 \\
\hline$\geq 3$ & 546 & $342 C$ & 28 & 391 & $308 C$ & 29 \\
\hline Total & 1,077 & 337 & 29 & 750 & 304 & 28 \\
\hline
\end{tabular}

a. Mean body mass differed among male age classes $(F=23.7, \mathrm{df}=2$ and 1,074, $P<0.01)$; means with different letters are different $(P<$ 0.05).

b. Mean body mass differed among female age classes $(F=12.3, \mathrm{df}=2$ and $747, P<0.01)$; means with different letters are different $(P<$ 0.05). 
(Depredation) DWP00-035 issued by the Department of Environmental Conservation. This study was approved by the National Wildlife Research Center Animal Care and Use Committee (QA 241).

\section{Literature Cited}

Belant, J. L., And R. A. Dolbeer. 1993. Population status of nesting Laughing Gulls in the United States, 1977-1991. American Birds 47:220-224.

Belant, J. L., And R. A. Dolbeer. 1996. Age classification of Laughing Gulls based on summer plumage. Journal of Field Ornithology 67:565-574.

Buckley, P. A., And M. M. Gurien. 1986. An ecological approach to the control of Laughing Gulls at John F. Kennedy International Airport, New York City. Final Report, National Park Service Cooperative Research Unit, Rutgers University, New Brunswick, New Jersey.

Burger, J. 1996. Laughing Gull (Larus atricilla). In The Birds of North America, no. 225 (A. Poole and F. Gill, Eds.). Academy of Natural Sciences, Philadelphia, and American Ornithologists' Union, Washington, D.C.

DolbeER, R. A. 1999. Aerodrome bird hazard prevention: Case study at John F. Kennedy International Airport. Pages 157-166 in Proceedings of the International Seminar on Flight Safety and Birds in the Middle East (Y. Leshem, Y. Mandelik, and J. ShamounBaranes, Eds.). International Center for the Study of Bird Migration, Latrun, Israel.

Dolbeer, R. A., S. C. Barras, And R. B. Chipman. 2002. Shooting gulls to reduce strikes with aircraft at John F. Kennedy International Airport, 1991-2001. Special Report for the Port Authority of New York and New Jersey, U.S. Department of Agriculture, National Wildlife Research Center, Sandusky, Ohio.

DolbeER, R. A., AND J. L. Belant. 1994. Differential band wear for male and female Laughing Gulls. Journal of Field Ornithology 65:543-550.

Dolbeer, R. A., J. L. Belant, And G. E. Bernhardt. 1997. Aerial photography techniques to esti- mate populations of Laughing Gull nests in Jamaica Bay, New York, 1992-1995. Colonial Waterbirds 20:8-13.

Dolbeer, R. A., J. L. Belant, And J. L. Sillings. 1993. Shooting gulls reduces strikes with aircraft at John F. Kennedy International Airport. Wildlife Society Bulletin 21:442-450.

Good, T. P. 1998. Great Black-backed Gull (Larus marinus). In The Birds of North America, no. 330 (A. Poole and F. Gill, Eds.). Academy of Natural Sciences, Philadelphia, and American Ornithologists' Union, Washington, D.C.

Grant, P. J. 1986. Gulls: A Guide to Identification, 2nd ed. Buteo Books, Vermilion, South Dakota.

Pearson, S. F., and S. Rohwer. 1998. Determining clutch size and laying dates using ovarian follicles. Journal of Field Ornithology 69: 587-594.

Pierotti, R. J., And T. P. Good. 1994. Herring Gull (Larus argentatus). In The Birds of North America, no. 124 (A. Poole and F. Gill, Eds.). Academy of Natural Sciences, Philadelphia, and American Ornithologists' Union, Washington, D.C.

Ryder, J. P. 1993. Ring-billed Gull (Larus delawarensis). In The Birds of North America, no. 33 (A. Poole, P. Stettenheim, and F. Gill, Eds.). Academy of Natural Sciences, Philadelphia, and American Ornithologists' Union, Washington, D.C.

Schreiber, R. W., ANd E. A. Schreiber. 1979. Notes on measurements, mortality, molt, and gonad condition in Florida west coast Laughing Gulls. Florida Field Naturalist 7:19-23.

STATISTIX. 2000. STATISTIX7 User's Manual. [Online.] Available at www.statistix.com. Analytical Software, Tallahassee, Florida.

Steel, R. G. D., and J. H. Torrie. 1980. Principles and Procedures of Statistics: A Biometrical Approach, 2nd ed. McGraw-Hill Book Company, New York.

Associate Editor: A. Burger 